\title{
Impact of e-banking service quality on e-loyalty in pandemic times through interplay of e-satisfaction
}

\author{
Inzamam U1 Haq and Tahir Mumtaz Awan \\ Department of Management Sciences, COMSATS University Islamabad, \\ Islamabad, Pakistan
}

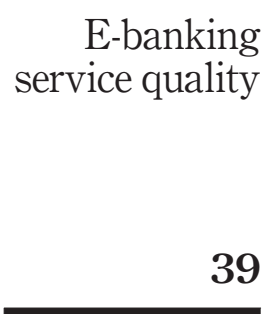

Received 23 July 2020 Revised 21 August 2020 31 August 2020 Accepted 1 September 2020

\begin{abstract}
Purpose - This study aims to empirically explore e-banking service quality and its impact on the e-banking loyalty through a mediating impact of e-banking satisfaction. The account holders of three domestic systemically important banks of Pakistan were surveyed during COVID-19 to examine the electronic services provided by these banks.

Design/methodology/approach - The data was collected through an adapted questionnaire by using emails and messaging applications. The database of a local marketing company in Pakistan was used, and 976 responses were included in the analysis. The structured equation modeling was used to test the propositions of study.

Findings - The findings delineate that reliability and website design proved to increase e-banking loyalty, particularly during COVID-19. The link between e-banking privacy and security and e-banking loyalty was proved as fully mediated by e-banking satisfaction; however, indirect effect of the reliability and website design with e-banking loyalty was partially mediated.

Practical implications - In strategic planning of e-banking mechanisms and the associated consumer behavior, the results of this study can be helpful for policymakers. In case of similar epidemics and natural calamities, consumers may depict similar behavior as shown during the lockdown and social distancing during COVID-19; hence, the study can help regulatory bodies in preparing their safety roadmap.

Originality/value - The mediating effect of e-banking satisfaction between privacy \& Security and ebanking loyalty implies that customer give importance to secure e-banking platforms. There can be a variation in their loyalty because of privacy concerns. The application of cognitive-motivational-relational (CMR) theory in a relationship between e-banking service quality and e-banking loyalty with a mediating role of satisfaction is an emotional response to capture the behavioral changes during COVID-19. It enables researchers to understand the CMR theory concerning COVID-19 and e-banking perspective.
\end{abstract}

Keywords E-banking service quality, E-banking satisfaction, E-banking loyalty, CMR theory, COVID-19, Domestic-Systemically important banks, Domestic systemically important banks, e-banking loyalty, e-banking satisfaction, e-banking service quality

Paper type Research paper
(C) Inzamam Ul Haq and Tahir Mumtaz Awan. Published in Vilakshan - XIMB Journal of Management. Published by Emerald Publishing Limited. This article is published under the Creative Commons Attribution (CC BY 4.0) licence. Anyone may reproduce, distribute, translate and create derivative works of this article (for both commercial and non-commercial purposes), subject to full attribution to the original publication and authors. The full terms of this licence may be seen at http:// creativecommons.org/licences/by/4.0/legalcode

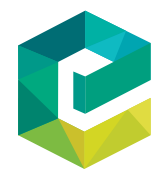

Vilakshan - XIMB Journal of Management Vol. 17 No. $1 / 2,2020$

Emerald Publishing Limited e-ISSN: 2633-9439 e-ISSN: 2633-9439
p-ISSN: 0973-1954 DOI 10.1108/XJM-07-2020-0039 
$\mathrm{XJM}$

$17,1 / 2$

\section{Introduction}

The advancement in information and communication technologies (ICT) has transformed way of doing business. Technology plays a bridging role in information and business processes. Along with other business entities, banks are also taking benefit of ICT since long. In almost every field, ICT is playing its role, e.g. business (Versteeg and Bouwman, 2006; Yi and Thomas, 2007), marketing (Qirici et al., 2011; Vilaseca-Requena et al., 2007), entrepreneurship (Malik et al., 2020) etc. We have seen transformations in the banking systems every other day and conventional banking is reducing. Digital banking is always a preference for account holders nowadays (Singh et al., 2017). It is pertinent to mention here that customer experience is always an important consideration for organizations (Mansoor et al., 2020). A recent pandemic (COVID-19) was also one of the uncertain situations which helped customers, employees and public in large realize changes in business models (Seetharaman, 2020). Banks noticed consumer's shift towards digital or electronic banking during the pandemic times (Baldwin and Mauro, 2020; Wójcik and Ioannou, 2020). There were rumors about spread of virus from cash notes which also became an important reason to tilt people toward e-banking (Auer et al., 2020; SivaKumar et al., 2020). The spread of this virus was very rapid (Novel, 2020), as it killed numberless people in nearly eight months (till August 2020). Along with the spread of virus, the fear termed as a social stigma and the real pandemic (Aslam et al., 2020) was noticed. The pandemic originated from China in the end of December (Zhu et al., 2020) and slowly shifting its epicenter from China to USA, then to Europe was reported. Multiple studies predicted the outbreak (Awan and Aslam, 2020) using different tools and techniques and gave policy recommendations which can be helpful (Aslam et al., 2020).

The foundation of banking services lies in the trust factor among the banks and consumers with an ultimate goal to provide quality services on lesser transaction costs (Shankar and Jebarajakirthy, 2019). Trust and loyalty holds great importance in electronic environments (Chaudhry et al., 2009). In pandemic situation, this importance amplifies dramatically as ICT is aimed toward not only new developments but also customer retention. This became of challenge for the banking industry also, especially in less developed countries, and role of knowledge management in commercial banks increased, which is termed as very important (Khokhar et al., 2010). Similarly quality of services was also termed as important in not only banking but also in other industries, e.g. restaurants (Malik et al., 2020; Malik et al., 2013; Safi and Awan, 2018), construction (Al-Momani, 2000; Love et al., 2000), education (Joseph and Joseph, 1997; Latif et al., 2019), etc.

The COVID-19 has changed the way people live, interact and make purchase decisions. The fear of COVID-19 is life threatening for people around the world (Mamun and Ullah, 2020). Particularly, students, these days are restricted to take a class online (Basilaia and Kvavadze, 2020), teachers and officials need to have online meetings (Basilaia et al., 2020; Sahu, 2020), and buyers and sellers are focusing on electronic means too (Hall et al., 2020; Rovetta and Bhagavathula, 2020). It's quite identical in the banking sector that digital means are getting popular as account holders are already much leaned toward online banking. Unpredictably, where COVID-19 has shutdown business around the world and put a huge number of people below the poverty line, ample opportunities are created e.g. for information technology businesses, telehealth care and security firms. Traditional banking has declined during the COVID-19, and consequently, increase in e-banking platforms is observed. Thus, the empirical potential to evaluate the banking services is needed to understand the behavioral changes. The noticeable boost has been observed toward ebanking practices during pandemic times in Pakistan too. Electronic banking built an efficient flow of services provided with reduced operational and fixed costs with more safety 
features incorporated. People in Pakistan are more leaned toward dealing with their banking needs through online means as they were not allowed to visit their bank branch. The debate of research moves around the remedies of research questions mainly dealing with how service quality and its dimensions are associated with the e-satisfaction and e-loyalty of banking system and how e-satisfaction mediates the relationship of service quality and eloyalty.

This study heavily supported the emerging concept of different e-banking services quality (EBSQ) characteristics under COVID-19 as compared to normal conditions. The horizon of this area of research is quite large as studies on multiple contexts e.g. retail industry (Kim et al., 2009; Ziaullah et al., 2014), healthcare (Gummerus et al., 2004), tourism (Kim et al., 2011), online shopping (Collier and Bienstock, 2006; Santouridis, 2009) etc. were found but there is less literature available in banking context, and very scarcely e-banking in the pandemic times is discussed in literature. This study adds into literature the EBSQ during this pandemic and captures dynamic user's behavior via cognitive-motivationalrelational (CMR) theory.

\section{Theoretical foundations and literature review \\ Cognitive-motivational-relational theory}

This study is theoretically backed by CMR theory as it connects the process of analyzing different perspectives and emotional responses of humans toward evaluation (Kemper, 1992; Lazarus, 1993; Lazarus and Lazarus, 1991). Emotion stimulates almost all the events which are significant in our lives moreover how to respond to them influences too (Kemper, 1992; Mansoor et al., 2020). Demographic traits determined the occurrence of cognitive orientation such as values, beliefs and personal objectives resulted in a significant repose toward an event within an environment (Shankar and Jebarajakirthy, 2019). There are multiple instances in literature where CMR theory is used to connect the mechanism of aspects of individual response and the quality of services (Bowen and Chen, 2001; Brady and Robertson, 2001; Shankar and Jebarajakirthy, 2019; Sivapalan and Jebarajakirthy, 2017); however, usage in COVID-19 contributes into the CMR literature differently. The response to environment or an event (COVID-19 in case of this study) elucidates the loyalty of customers in e-banking, which can be termed as an addition in the theoretical aspects.

\section{E-banking service quality and e-banking loyalty}

It is extensively discussed in literature that loyalty depends on EBSQ (Hussien and Aziz, 2017; Shankar and Jebarajakirthy, 2019). There are four dimensions of EBSQ, namely, reliability, privacy and security, website design and customer service and support of ebanking. The first dimension, reliability in e-banking holds great importance as response of customers is crucial. Reliability is one of the factors which can influence responses, however timely processing of banking transactions with zero errors is often taken essentially in judging the reality of e-banking service providers (Blut et al., 2014; Liang and Pei-Ching, 2015; Saccani et al., 2014). The second dimension, privacy and security expresses the extent to which an e-banking user confidently shares personal information on an e-banking platform (Muturi et al., 2013). E-banking creates serious privacy issues for the users as there is no in-person interaction (Kim et al., 2009; Shankar and Jebarajakirthy, 2019). However, the trust factor surged toward service providers and the desired customer satisfaction response can be achieved through trust (Safi and Awan, 2018). The better code of conduct for privacy and safety results in higher loyalty (Orel and Kara, 2014; Thaichon et al., 2014). The third dimension of EBSQ, website design is defined as various interactive features of the ebanking service helps provide consumers with structure of transaction during and 
$\mathrm{XJM}$

$17,1 / 2$

summary afterwards the structure of processing a transaction and more (Wolfinbarger and Gilly, 2003). Higher level of satisfaction can be achieved through an updated website (Kim et al., 2009) and enhanced interactive experience. The traits of interactive websites enhances trust, satisfaction and loyalty toward the e-banking results (Lee et al., 2006). The fourth dimension, customer service and support can be explained as the rapidity of retort toward any delinquent reported by user during or after service experience. The users here can be referred as both individuals and organizations (Blut et al., 2015). Similar to the individual users, organizations are also much concerned, which sometimes also have a deeper impression on employees as well (Awan et al., 2017). The support provided by the banking professional are considered more secured and assured while any trouble is faced in India (Shankar and Jebarajakirthy, 2019) and similar case is expected in Pakistan as well. The adaptation in website design leads consumers to trouble (Thaichon et al., 2014) while the quick and effective solution provided on time to user results into higher satisfaction leading to loyalty in electronic environments generally (Chaudhry et al., 2009) and in e-banking more specifically (Shankar and Jebarajakirthy, 2019). Resultantly, all four dimensions are hypothesized as follows for empirical testing.

H1. Reliability in e-banking services positively influences e-banking loyalty.

H2. Privacy and security in e-banking services positively influence e-banking loyalty.

H3. Website design in e-banking services positively influences e-banking loyalty.

H4. Customer service and support in e-banking services positively influence e-banking loyalty.

\section{E-banking service quality and e-banking satisfaction}

The relationship of EBSQ and satisfaction remains a great academic debate (Esengun $e$ t al., 2006; Haider et al., 2014; Shankar and Jebarajakirthy, 2019; Wang and Ma, 2010; Shankar and Jebarajakirthy, 2019). Contradictory findings and views of researchers can be noted, as some argued EBSQ as an antecedent of e-banking customer satisfaction (Shankar and Jebarajakirthy, 2019). Older studies termed satisfaction as antecedent of service quality (Cronin et al., 2000; Cronin and Taylor, 1992; Dick and Basu, 1994; Parasuraman et al., 1985) and the findings of these classical studies cannot be neglected even if the service quality is now read as electronic service quality and digital aspect is also attached to satisfaction and loyalty. An empirical analysis of customer perception of US banks on service quality reports higher quality of EBSQ leads to satisfaction (Foroughi et al., 2019). Website attributes undoubtedly play a vital role in improving customer satisfaction (Amin, 2016; Roy et al., 2012) however variety of attributes have different impressions on the minds of consumers (Bressolles et al., 2014). This vividly demonstrated the relationship between website design and e-banking customer satisfaction. Support services provided during e-banking should be less technical as satisfaction among users varies because of technicality of services (Black et al., 2014). Thus customer service and support need to be smooth and favorable for achieving higher satisfaction (Shankar and Jebarajakirthy, 2019). To achieve satisfaction and for greater customer loyalty, privacy and navigation interface must be focused (Bressolles et al., 2014). The service providers especially in e-banking are strictly advised to ensure focus on high level of secure information, confidentiality and transaction privacy (Brun et al., 2014; Yu et al., 2015). Significant impact of EBSQ on customer satisfaction in ebanking is also reported in this context (Kassim and Abdullah, 2010). Hence, below hypothesis are formulated to empirically test in e-banking during COVID-19. 
H5. Reliability in e-banking services positively influences e-banking satisfaction.

H6. Privacy and security in e-banking services positively influence e-banking satisfaction.

H7. Website design in e-banking services positively influences e-banking satisfaction.

H8. Customer service and support in e-banking services positively influence e-banking satisfaction.

\section{Mediating role of e-banking satisfaction}

Generally, businesses always strive for higher customer satisfaction, being a core element. Beyond doubt, loyalty of customers can be attained by provision of higher levels of satisfaction to them. In tourism, satisfied tourists happily convert into loyal ones (Mahadin et al., 2020). E-satisfaction leads toward attitudinal loyalty consequently leaving a positive impact on behavior. E-satisfaction in banking can leads to more usage of banking services with higher possibilities of e-loyalty (Giao et al., 2020; Suariedewi and Suprapti, 2020). The internet speed and connectivity often influences satisfaction and impact loyalty also (Chaudhry et al., 2009). E-trust and e-satisfaction mediate the relationship between the services service quality (Giao et al., 2020). In recent literature, studies have been discussed the strong relationship between esatisfaction and e-loyalty however, in the context of pandemic scarce literature measured impact of e-banking satisfaction and e-banking loyalty. Hence, the below empirical propositions were formulated and tested in this study. The framework in figure 1 shows all hypotheses.

H9. E-banking satisfaction positively influences e-banking loyalty.

H10. E-banking satisfaction positively mediates the relationship between e-banking service quality and e-banking loyalty

\section{Methodology}

The data was collected from the users of three domestic systemically important banks (DSIBs) as per the recent listing of State Bank of Pakistan, namely, National Bank of Pakistan, Habib Bank Limited and United Bank Limited. A structured questionnaire was adapted questionnaire was used to collect responses through convenience sampling. Online

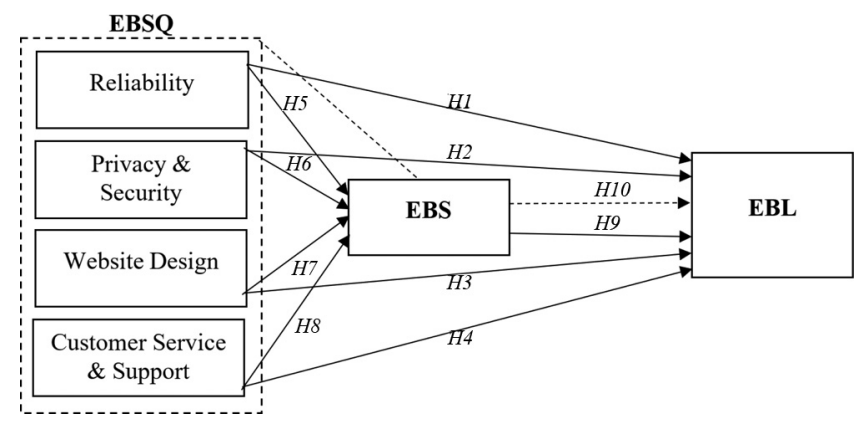

Figure 1. Conceptual framework 
$\mathrm{XJM}$

$17,1 / 2$

link was sent to the account holders of DSIBs using emails and messaging applications. The data of 3000 account holders was purchased from a local email and messaging marketing company. A total of 1,102 responses were received and 976 deemed usable for further analysis and remaining 126 being incomplete were discarded.

The scale was adapted according to the e-banking in pandemic needs with special attention to that meaning of constructs did not changed. Two experts in the DSIBs and one university professor verified the scale which was then used in the questionnaire. The demographics information was also collected in the same questionnaire in a separate section. The four components of ESBQ were measured using different scales; reliability was measured by four items (Jayawardhena, 2004; Muturi et al., 2013), privacy and security was operationalized by three items (Quach et al., 2016), website design was measured by four items (Jayawardhena, 2004) and five items were used to measure customer service and support (Quach et al., 2016; Wolfinbarger and Gilly, 2003). The other two variables EBS and EBL were measured using five and four items respectively (Amin, 2016). The responses were measured on a 5-point Likert scale ranging from strongly disagree (1) to strongly agree (5).

\section{Results}

Demographics analysis

The surveyed bank account holders had a larger ratio of males $(72.23 \%)$ as compared to females (27.77\%). Most of them (699) were young adults, with an age range 18-27 years, which makes $71.61 \%$ of the total followed by 214 respondents with age range $28-$ 37 years. The least (39) were in the age range $48-57$ years. The monthly income ranged from a minimum of 30,000 or lesser to 91,000 or higher considering much variations in the remuneration system in Pakistan, as well as the reason data was taken from people from all professions. The respondents with a salary of 30,000 or lesser encompassed around $45 \%$ of the total which shows that either they are working on low wage rate in the private sector. Least of them (13) fall under the income level ranging from 71,000 to 80,000 . More than half of the respondents $(58 \%)$ are working in private sector and least $(1 \%)$ were self-employed in the sample. There was also a representation of students (274) in the sample. Most of the bank account holders $(81.45 \%)$ frequently uses ebanking platform and nearly $94 \%$ believed e-banking is more useful than the conventional banking particularly because of lockdown restrictions, time and costeffectiveness. As they believed e-banking is useful for them and saves money and time too, trust showed on e-banking during COVID-19 is significant. The detailed demographic information of the sample is provided in Table 1.

\section{Measurement model assessment}

To ensure the reliability and validity among constructs, measurement analysis is recommended (Hair et al., 2010). Convergent and discriminant validity were examined through factor loadings, average variance extracted (AVE) and composite reliability (CR) values (Cheah et al., 2018). The cutoff point for each measure varies, factors loading value must be greater or equal to 0.70 or 0.50 , and Cronbach's alpha and CR values falling between 0.60 and 0.70 are acceptable (Hair et al., 2010). The acceptable AVE values should be 0.50 or greater (Cheah et al., 2018) by comparing diagonal values with the correlation coefficients for each construct in the relevant rows and columns (Hair et al., 2010). Table 2 depicts that all the values are in range, except three items which were deleted because of lower factor loadings and further analysis was performed. The values of all constructs indicated good 


\begin{tabular}{|c|c|c|c|}
\hline Category & No. of Respondents & $(\%)$ & $\begin{array}{l}\text { E-banking } \\
\text { service }\end{array}$ \\
\hline $\begin{array}{l}\text { Gender } \\
\text { Male } \\
\text { Female }\end{array}$ & $\begin{array}{l}705 \\
271\end{array}$ & $\begin{array}{l}72.23 \\
27.77\end{array}$ & \\
\hline $\begin{array}{l}\text { Age } \\
18-27 \text { Years } \\
\text { 28-37 Years } \\
\text { 37-47 Years } \\
48-57 \text { Years }\end{array}$ & $\begin{array}{r}699 \\
214 \\
48 \\
39\end{array}$ & $\begin{array}{r}71.61 \\
21.92 \\
4.91 \\
3.99\end{array}$ & 45 \\
\hline $\begin{array}{l}\text { Monthly Income (PKR) } \\
30,000 \text { or Less } \\
31,000-40,000 \\
41,000-50,000 \\
51,000-60,000 \\
61,000-70,000 \\
71,000-80,000 \\
81,000-90,000 \\
91,000 \text { or Higher }\end{array}$ & $\begin{array}{r}440 \\
138 \\
154 \\
107 \\
60 \\
13 \\
28 \\
60\end{array}$ & $\begin{array}{r}45.08 \\
14.13 \\
15.77 \\
10.96 \\
6.14 \\
1.33 \\
2.86 \\
6.14\end{array}$ & \\
\hline $\begin{array}{l}\text { Profession } \\
\text { Government Employees } \\
\text { Private Employees } \\
\text { Self-Employed } \\
\text { Students }\end{array}$ & $\begin{array}{r}126 \\
566 \\
10 \\
274\end{array}$ & $\begin{array}{c}12.9 \\
57.99 \\
1.02 \\
28.07\end{array}$ & \\
\hline $\begin{array}{l}\text { Bank Account } \\
\text { HBL } \\
\text { UBL } \\
\text { NBP }\end{array}$ & $\begin{array}{l}330 \\
307 \\
339\end{array}$ & $\begin{array}{l}33.81 \\
31.45 \\
34.73\end{array}$ & \\
\hline $\begin{array}{l}\text { E-banking Usage Frequency } \\
\text { Frequent User } \\
\text { Not a Frequent User }\end{array}$ & $\begin{array}{l}795 \\
181\end{array}$ & $\begin{array}{l}81.45 \\
18.55\end{array}$ & \\
\hline $\begin{array}{l}\text { E-banking Usefulness } \\
\text { Useful } \\
\text { Not Useful }\end{array}$ & $\begin{array}{r}914 \\
62\end{array}$ & $\begin{array}{r}93.64 \\
6.26\end{array}$ & \\
\hline $\begin{array}{l}\text { E-banking Cost and Timesaving } \\
\text { Yes } \\
\text { No } \\
\text { E-banking Mobile Application's Trustworthiness } \\
\text { Yes } \\
\text { No }\end{array}$ & $\begin{array}{r}878 \\
98 \\
\\
633 \\
343\end{array}$ & $\begin{array}{l}89.95 \\
10.05 \\
\\
64.85 \\
35.14\end{array}$ & $\begin{array}{r}\text { Table 1. } \\
\text { Demographics of } \\
\text { respondents }\end{array}$ \\
\hline
\end{tabular}

validity, consistency and accuracy of the measurement model. The graphical representation of measurement model assessment is provided in Figure 2.

The discriminant validity was then examined using the Hetrotrait-Monotrait (HTMT) ratios under the prescribed criteria (Franke and Sarstedt, 2019). As shown in Table 3, all the ratios are within range. The convergent validity was confirmed through Fornell-Lacker criterion and all the values were within the range and defined criteria. The values were found within the range and are depicted in Table 4. 


Items Statements $\quad$ F

Reliability AVE

(0.75), CR (0.90) $\alpha$

$(0.83)$

\section{6}

Privacy and Security AVE (0.57),

CR $(0.80) \alpha(0.62)$

Website Design AVE (0.053), CR (0.82) $\alpha(0.73)$

Customer Service and Support AVE (0.74), CR (0.92) $\alpha$ $(0.90)$

E-banking website provides the services exactly as promised during FL

\section{COVID-19}

E-banking always provides the services at the promised time during COVID-19

Using e-banking, I can retrieve the transaction details on my account during COVID-19

The information provided over the e-banking website is accurate during COVID-19

My personal information is protected on the e-banking platform during COVID-19

My financial information is protected on the e-banking platform during COVID-19

The transactions over the e-banking website are secured during COVID-19

The e-banking website is updated regularly during COVID-19

0.804

The e-banking website is well organized during COVID-19

The e-banking website includes interactive features during COVID-19

The e-banking website is easy to use during COVID-19

Customer service personnel are knowledgeable of e-banking services during COVID-19

Customer service personnel are always willing to help me with matters relating to e-banking during COVID-19

My queries relating to e-banking are answered promptly during COVID-19

E-banking customer care team has customers' best interests at heart during COVID-19

E-banking customer care team can be accessed at any time (24/7 operating hours) during COVID-19

E-banking Satisfaction AVE $(0.75)$, CR $(0.92) \alpha$ $(0.89)$

I am generally pleased with this bank's online services during COVID-19

I am very satisfied with this bank's online services during COVID-19

I am happy with this online bank during COVID-19

The website of online banks is simple to use during COVID-19

I am satisfied with the overall online bank's products and services during COVID-19

E-banking Loyalty

Table 2. AVE (0.79), CR

I will recommend e-banking to other people during COVID-19

0.916

Del

0.869

0.688

0.779

0.782

0.734

0.798

0.630

0.742

0.766

0.909

0.910

0.838

I prefer e-banking above other channels of banking during COVID-19

I would like to say positive things about e-banking to other people during COVID-19

I intend to continue using e-banking during COVID-19

\section{Structural model assessment}

The estimation of a structural model was established through path analysis. Generally, the estimation of VIF, $R^{2}$, Beta and $f^{2}$ while focusing on the $t$-values are considered for structural model assessment under bootstrapping process. A bootstrap with a subsample of 5,000 to improve the statistical significance of items weightage was performed as per the statistical guidelines (Cheah et al., 2018). The VIF measures the extent to which the multicollinearity issues make biases in regression outcomes. The value above 5 depicted the collinearity issues among the items of the variable (Fornell, 1994). The value of $R^{2}$ exhibits the changes in the response variable because of the existence of an endogenous variable. Moreover, the higher the value of $R^{2}$ it will satisfy the predictive accuracy (ranges from 0 to 1 ). The value of $f^{2}$ confirms whether the exclusion of the predictor has any influence on the endogenous variable and is measured to check the size of effect because the $p$-value is the indicator of 


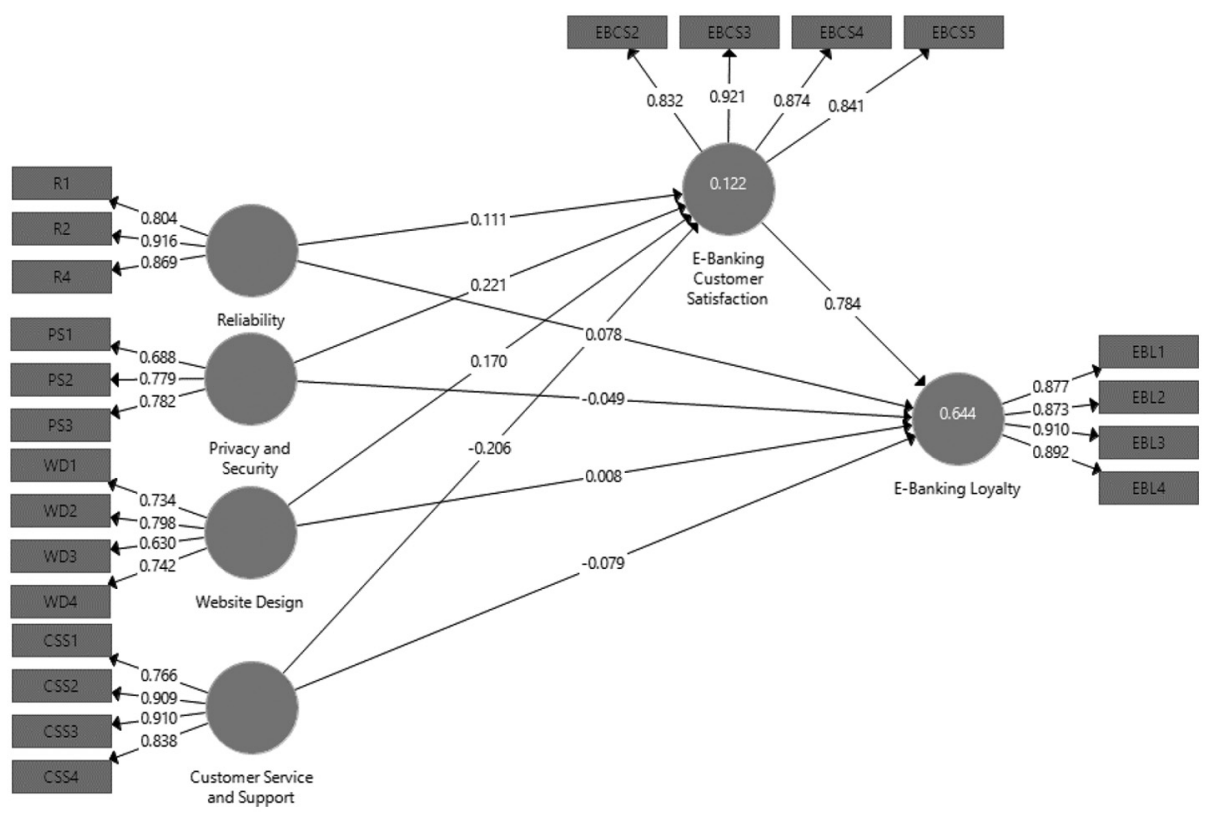

\section{E-banking service quality}

Figure 2.

Measurement model assessment

\begin{tabular}{|c|c|c|c|c|c|c|c|c|}
\hline & & 1 & 2 & 3 & 4 & 5 & 6 & \\
\hline 1 & Customer Service and Support & & & & & & & \\
\hline 2 & E-Banking Satisfaction & 0.071 & & & & & & \\
\hline 3 & E-Banking Loyalty & 0.127 & 0.843 & & & & & \\
\hline 4 & Privacy and Security & 0.521 & 0.305 & 0.187 & & & & Table 3. \\
\hline 5 & Reliability & 0.261 & 0.244 & 0.234 & 0.764 & & & Discriminant validity \\
\hline \multirow[t]{2}{*}{6} & Website Design & 0.283 & 0.221 & 0.162 & 0.297 & 0.224 & & (HTMT ratios) \\
\hline & & 1 & 2 & 3 & 4 & 5 & 6 & \\
\hline 1 & Customer Service and Support & 0.625 & & & & & & \\
\hline 2 & E-Banking Satisfaction & -0.119 & 0.775 & & & & & \\
\hline 3 & E-Banking Loyalty & -0.234 & 0.761 & 0.888 & & & & Table 4. \\
\hline 4 & Privacy and Security & 0.164 & 0.270 & 0.145 & 0.752 & & & Convergent validity \\
\hline 5 & Reliability & -0.125 & 0.288 & 0.253 & 0.451 & 0.745 & & (Fornell-Lacker \\
\hline 6 & Website Design & 0.139 & 0.207 & 0.148 & 0.203 & 0.174 & 0.729 & criterion) \\
\hline
\end{tabular}

showcasing the effect only but not the size of the effect, thus $f^{2}$ has significance (Ahmad et al., 2019).

Usually $\beta, p$-values and t-values are considered to accept or reject the hypothesis. Interestingly, $H 1$ and $H 3$ were accepted $(\beta=0.078$, $t$-values $=3.218$ and $p$-value $=0.001$ 
$\mathrm{XJM}$

$17,1 / 2$

and $\beta=0.08, t$-values $=0.3363, p$-value $=0.353)$ and $H 2$ and $H 4$ were rejected $(\beta=-0.049$, $t$-values $=1.819, p-$ value $=0.035$ and $\beta=-0.079, t$-value $=3.231, p-$ value $=0.001)$. The results confirmed, two predictors (reliability and website design) influence negatively however (privacy and security and customer service and support) effect positively. These results are inconsistent with the previous literature (Shankar and Jebarajakirthy, 2019). The results of $H 5, H 6$ and $H 7$, respectively, demonstrated $\beta=0.111, t$-values $=3.052$, $p$-value $=$ $0.001, \beta=0.221$, $t$-values $=5.519, p$-value $=0.000$ and $\beta=0.17, t$-values $=5.798, p$-value $=$ 0.000 , reporting the positive influence of e-banking customer satisfaction on loyalty. In contrast, in $H 8$ the negative effect on loyalty was reported $(\beta=-0.206, t-$ value $=5.113, p-$ value $=0.000$ ). Finally, $H 9$ with $\beta=0.784, t-$ value $=9.726, p-$ value $=0.000$ confirmed the proposed hypothesis and significant positive impact was proved.

$H 10$ confirmed the mediation of EBS between reliability and EBL with $\beta=0.087$ and, $t-$ value $=3.058$ however the tendency of $0.087, L L=0.138, U L=0.046$ under $95 \%$ (confidence interval) boot and did not overlap the zero among certain values for mediation confirmation. Likewise, the mediation of EBS in-between privacy and security and EBL $\beta=0.173$ and, $t-$ value $=5.466$ however the tendency of $0.173, L L=0.225, U L=0.133$ under $95 \%$ (confidence interval). Similarly, the mediation of EBS between website design and EBL with $\beta=0.133$ and, $t$-value $=5.778$ however the tendency of $0.133, L L=0.169, U L=0.093$ under $95 \%$ (confidence interval). The mediation effect EBS among customer service and support and EBL with $\beta=-0.162$ and, $t-$ value $=4.553$ however the tendency of $L L=-0.133, U L=$ -0.195 under $95 \%$ (confidence interval) boot and did not overlapped the zero among certain values but a significant negative relationship was observed, hence, mediation was approved. Moreover, $f^{2}$ determines effect size, and the large, medium and low categories are classified within the range of $0.35,0.15$ and 0.02 respectively. In this study, $f^{2}$ values are; one (large), seven (medium) and one (low). The detailed tabulation is given in Table 5.

\section{Discussion}

This study was conducted not only to improve the e-banking loyalty through utilizing and offering high-quality services in e-banking environment, but also to check the behavioral changes in account holders during the pandemic times. The findings are consistent with earlier researchers (Blut et al., 2015; Chaudhry et al., 2009; Safi and Awan, 2018; Shankar and Jebarajakirthy, 2019) with some exceptions probably because of this hard time of COVID-19. The insignificant relationship of privacy and security and customer service and support was proved, mediation wasn't expected (Quach et al., 2016). The findings are novel as people usually do not pay attention toward website design because of busy schedules; however, they are concerned about website design and reliability. The account holders need to be satisfied from the customer services and support which then becomes a source of loyalty during COVID-19. Therefore, the indirect effect of reliability and website design on EBL via EBS proved to be partially mediated however the customer service and support confirmed full mediation. The rejected indirect effect of customer service and support on e-banking loyalty via e-banking satisfaction might be the reason people did not find their problems are fully resolved by the customer service and support department during the pandemic times. The customers will never be satisfied and loyal until and unless his problem and concern will not be addressed, hence serious concern of banks and similar organizations is needed especially during the hard times same as Coronavirus pandemic. The structured responses recorded or generated through ICT or artificial intelligence applications has a limited amount of information and may not solve the problem. Hence, this study helped to enhance the literature and supported EBSQ to be used in these epidemic studies also. E-banking 


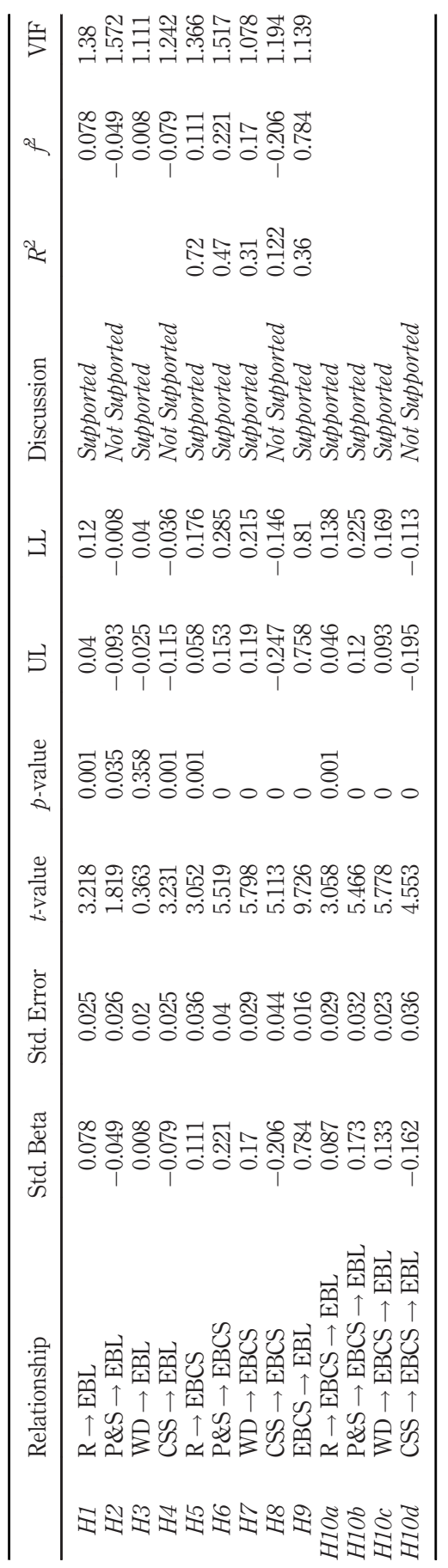

Table 5. Hypotheses testing (direct and indirect effects) 
$\mathrm{XJM}$

$17,1 / 2$

facilities and services should be offered in a way which attract consumers with costefficiency as the main focus.

\section{Conclusion, implications and future research}

The current circumstances progress the requirement of e-banking, had a critical influence on the usage of conventional banking and focused on the influence during the pandemic, however their preferences related to trust, safety and security, reliability, website designs and customer support, and an interesting change from previous literature is noted. The probable reason is the hard times of the ongoing pandemic (COVID-19).

This study brought an addition to the literature where CMR theory can be applied to support our framework, thus providing strength to it. This research highlights the association of CMR with COVID-19 thus contributes to the CMR literature in a divergent manner. Predominantly, the significance of DSIBs is important and no study considering the account holders was conducted. The State Bank of Pakistan thus can take benefit from this study to design policies regarding e-banking especially in the hard times of epidemics and natural calamities that can help banks retain their existing accounts holders and attract new as well. Moreover, service providers can also understand customer's perception and factors which make them more satisfied and loyal toward e-banking services. Also, this study serves as a source of understanding for customers' priorities and focuses required from ebanking services to become loyal and satisfied from the online banking platforms during the lockdown. Additionally, it assists banks in strategic decisions making for improvements in the e-banking future of Pakistan and manage COVID-19 and digitalization.

This research was limited to Pakistan's e-banking environment because of accessibility issue of respondents and time constraint as quick research is needed and appreciated in these unprecedented times. We have considered only the mediated impact of e-banking customer satisfaction moreover it was quite difficult for us to build a relationship between EBSQ dimensions with e-banking satisfaction because of relatively less literature in the similar context. Further research also can empirically verify the relationship of initial trust along with customer satisfaction in e-banking and can consider banks data from multiple nations. A comparative study of Asians with other regions can be a useful study. Also, future research should consider the combination of strategic management theories to study the relationship of EBSQ. Interestingly, at very less instances (U1 Haq et al., 2020), VRIO framework is considered for empirical testing especially as a mediator. Thus, another recommendation is including the VRIO framework as a mediator will may result in some interesting findings.

\section{References}

Ahmad, N.H. Ramayah, T. Mahmud, I. Musa, M. and Anika, J.J. (2019), "Entrepreneurship as a preferred career option. Education+ training"

Al-Momani, A.H. (2000), "Examining service quality within construction processes", Technovation, Vol. 20 No. 11, pp. 643-651.

Amin, M. (2016), "Internet banking service quality and its implication on e-customer satisfaction and ecustomer loyalty", International Journal of Bank Marketing., Vol. 34 No. 3,

Aslam, F., Awan, T.M., Syed, J.H., Kashif, A. and Parveen, M. (2020), "Sentiments and emotions evoked by news headlines of coronavirus disease (COVID-19) outbreak", Humanities and Social Sciences Communications, Vol. 7 No. 1, pp. 1-9.

Auer, R. Cornelli, G. and Frost, J. (2020), “Covid-19, cash, and the future of payments. Retrieved from”, 
Awan, T.M. and Aslam, F. (2020), "Prediction of daily COVID-19 cases in European countries using automatic ARIMA model", Journal of Public Health Research, Vol. 9 No. 3.

Awan, T.M., Li, X. and Haizhong, W. (2017), "Factors affecting employee-based brand equity: evidence from China", International Journal of Management Studies, Vol. 25 No. 1, pp. 1-20.

Baldwin, R. and Mauro, B. W. D. (2020), Economics in the Time of COVID-19, CEPR Press.

Basilaia, G., Dgebuadze, M., Kantaria, M. and Chokhonelidze, G. (2020), "Replacing the classic learning form at universities as an immediate response to the COVID-19 virus infection in Georgia", International Journal for Research in Applied Science and Engineering Technology (Technology), Vol. 8 No. 3, pp. 101-108.

Basilaia, G. and Kvavadze, D. (2020), "Transition to online education in schools during a SARS-CoV-2 coronavirus (COVID-19) pandemic in Georgia”, Pedagogical Research, Vol. 5 No. 4, pp. 1-9.

Black, H.G., Childers, C.Y. and Vincent, L.H. (2014), "Service characteristics' impact on key service quality relationships: a meta-analysis", Journal of Services Marketing,

Blut, M., Beatty, S.E., Evanschitzky, H. and Brock, C. (2014), "The impact of service characteristics on the switching costs-customer loyalty link", Journal of Retailing, Vol. 90 No. 2, pp. 275-290.

Blut, M., Frennea, C.M., Mittal, V. and Mothersbaugh, D.L. (2015), "How procedural, financial and relational switching costs affect customer satisfaction, repurchase intentions, and repurchase behavior: a Meta-analysis", International Journal of Research in Marketing, Vol. 32 No. 2, pp. 226-229.

Bowen, J.T. and Chen, S.L. (2001), "The relationship between customer loyalty and customer satisfaction", International Journal of Contemporary Hospitality Management, Vol. 13 No. 5.

Brady, M.K. and Robertson, C.J. (2001), "Searching for a consensus on the antecedent role of service quality and satisfaction: an exploratory cross-national study", Journal of Business Research, Vol. 51 No. 1, pp. 53-60.

Bressolles, G., Durrieu, F. and Senecal, S. (2014), “A consumer typology based on e-service quality and e-satisfaction”, Journal of Retailing and Consumer Services, Vol. 21 No. 6, pp. 889-896.

Brun, I., Rajaobelina, L. and Ricard, L. (2014), "Online relationship quality: scale development and initial testing”, International Journal of Bank Marketing, Vol. 32 No. 1.

Chaudhry, I.G., Abbas, Q., Awan, T.M. and Ghafoor, A. (2009), "Trust, satisfaction and E-Loyalty in Pakistan's electronic commerce", Paper presented at the e-CASE 2019 - International Conference on e-Commerce, e-Administration, e-Society, and e-Education, Singapore.

Cheah, J.-H., Sarstedt, M., Ringle, C.M., Ramayah, T. and Ting, H. (2018), "Convergent validity assessment of formatively measured constructs in PLS-SEM", International Journal of Contemporary Hospitality Management, Vol. 30 No. 11.

Collier, J.E. and Bienstock, C.C. (2006), "Measuring service quality in e-retailing", Journal of Service Research, Vol. 8 No. 3, pp. 260-275.

Cronin, J.J., Jr. and Taylor, S.A. (1992), "Measuring service quality: a reexamination and extension", Journal of Marketing, Vol. 56 No. 3, pp. 55-68.

Cronin, J.J., Jr, Brady, M.K. and Hult, G.T.M. (2000), “Assessing the effects of quality, value, and customer satisfaction on consumer behavioral intentions in service environments", Journal of Retailing, Vol. 76 No. 2, pp. 193-218.

Dick, A.S. and Basu, K. (1994), "Customer loyalty: toward an integrated conceptual framework”, Journal of the Academy of Marketing Science, Vol. 22 No. 2, pp. 99-113.

Esengun, K., Gunduz, O., Akay, M. and Cicek, A. (2006), "Assessment of the local governments efforts in challenging to environmental problems using factor analysis: a case study of Turkey", JApSc, Vol. 6 No. 5, pp. 1052-1058.

Fornell, C. (1994), "Partial least squares. Advanced methods of marketing research", 
$\mathrm{XJM}$

$17,1 / 2$

Foroughi, B., Iranmanesh, M. and Hyun, S.S. (2019), "Understanding the determinants of mobile banking continuance usage intention", Journal of Enterprise Information Management, Vol. 32 No. 6.

Franke, G. and Sarstedt, M. (2019), "Heuristics versus statistics in discriminant validity testing: a comparison of four procedures", Internet Research, Vol. 29 No. 3.

Giao, H., Vuong, B. and Quan, T. (2020), “The influence of website quality on consumer's e-loyalty through the mediating role of e-trust and e-satisfaction: an evidence from online shopping in Vietnam”, Uncertain Supply Chain Management, Vol. 8 No. 2, pp. 351-370.

Gummerus, J., Liljander, V., Pura, M. and Van Riel, A. (2004), "Customer loyalty to content-based web sites: the case of an online health-care service", Journal of Services Marketing, Vol. 18 No. 3.

Haider, M.Z., Janjua, S.Y. and Ahmad, M. (2014), "Advertising spending and brand loyalty: a case from Pakistani market”, International Journal of Information, Business and Management, Vol. 6 No. 1, pp. 52.

Hair, J.F., Anderson, R.E., Babin, B.J. and Black, W.C. (2010), Multivariate Data Analysis: A Global Perspective, (Vol. 7). In: Upper Saddle River, NJ: Pearson.

Hall, M.C., Prayag, G., Fieger, P. and Dyason, D. (2020), "Beyond panic buying: consumption displacement and COVID-19", Journal of Service Management.

Hussien, M.I. and Aziz, R.A.E. (2017), "System dynamics modeling and simulation for E-Banking: the Egyptian context", IBIMA Business Review, Vol. 2017

Jayawardhena, C. (2004), "Measurement of service quality in internet banking: the development of an instrument", Journal of Marketing Management, Vol. 20 Nos 1/2, pp. 185-207.

Joseph, M. and Joseph, B. (1997), "Service quality in education: a student perspective", Quality Assurance in Education, Vol. 5 No. 1.

Kassim, N. and Abdullah, N.A. (2010), "The effect of perceived service quality dimensions on customer satisfaction, trust, and loyalty in e-commerce settings", Asia Pacific Journal of Marketing and Logistics, Vol. 22 No. 3.

Kemper, T.D. (1992), "Emotion and adaptation”, In Jstor,

Khokhar, A.G.C.S.H., Chaudhry, I.G. and Awan, T.M. (2010), "Role of knowledge management processes in the commercial banks in Pakistan", Paper presented at the 2nd South Asian International Conference (SAICON) 2010 - Nurturing Innovation, Entrepreneurship, Investment and Public Private Partnership in Global Environment, Pakistan.

Kim, M.J., Chung, N. and Lee, C.-K. (2011), "The effect of perceived trust on electronic commerce: shopping online for tourism products and services in South Korea", Tourism Management, Vol. 32 No. 2, pp. 256-265.

Kim, J., Jin, B. and Swinney, J.L. (2009), “The role of etail quality, e-satisfaction and e-trust in online loyalty development process", Journal of Retailing and Consumer Services, Vol. 16 No. 4, pp. 239-247.

Latif, K.F., Latif, I., Sahibzada, U. and Ullah, M. (2019), "In search of quality: measuring higher education service quality (HiEduQual)", Total Quality Management and Business Excellence, Vol. 30 Nos 7/8, pp. 768-791.

Lazarus, R.S. (1993), "From psychological stress to the emotions: a history of changing outlooks", Annual Review of Psychology, Vol. 44 No. 1, pp. 1-22.

Lazarus, R.S. and Lazarus, R.S. (1991), Emotion and Adaptation, Oxford University Press on Demand.

Lee, H.H., Fiore, A.M. and Kim, J. (2006), "The role of the technology acceptance model in explaining effects of image interactivity technology on consumer responses", International Journal of Retail and Distribution Management, Vol. 34 No. 8.

Liang, C.-C. and Pei-Ching, W. (2015), "Internet-banking customer analysis based on perceptions of service quality in Taiwan”, Total Quality Management and Business Excellence, Vol. 26 No. 5-6, pp. 550-568. 
Love, P.E., Smith, J., Treloar, G. and Li, H. (2000), "Some empirical observations of service quality in construction", Engineering, Construction and Architectural Management, Vol. 7 No. 2, pp. 191-201.

Mahadin, B., Akroush, M.N. and Bata, H. (2020), "The effects of tourism websites' attributes on esatisfaction and e-loyalty: a case of American travellers' to Jordan”, International Journal of Web Based Communities, Vol. 16 No. 1, pp. 4-33.

Malik, S., Awan, T.M. and Nisar, A. (2020), "Entrepreneurial leadership and employee innovative behaviour in software industry”, Journal of Business and Economics, Vol. 12 No. 1, pp. 63-76.

Malik, S.A., Akhtar, F., Raziq, M.M. and Ahmad, M. (2020), "Measuring service quality perceptions of customers in the hotel industry of Pakistan", Total Quality Management and Business Excellence, Vol. 31 Nos 3/4, pp. 263-278.

Malik, S., Jaswal, L.H., Malik, S.A. and Awan, T.M. (2013), "Measuring service quality perceptions of the customers of restaurant in Pakistan", International Journal for Quality Research, Vol. 7 No. 2 , pp. 187-200.

Mamun, M.A. and Ullah, I. (2020), "COVID-19 suicides in Pakistan, dying off not COVID-19 fear but poverty? The forthcoming economic challenges for a developing country", Brain, Behavior, and Immunity, Vol. 87

Mansoor, M., Awan, T.M. and Alobidyeen, B. (2020), "Structure and measurement of customer experience management”, International Journal of Business and Administrative Studies, Vol. 6 No. 4, pp. 171-182.

Mansoor, M., Awan, T.M. and Syed, F. (2020), "Positive emotions as underlying mechanism between customer gratitude and behavioural intentions", Journal of Administrative and Business Studies, Vol. 6 No. 1, pp. 9-20.

Muturi, D., Sagwe, J., Hussien, M.I. and Abd El Aziz, R. (2013), "Investigating e-banking service quality in one of Egypt's banks: a stakeholder analysis", The TQM Journal,

Novel, C.P.E.R.E. (2020), "The epidemiological characteristics of an outbreak of 2019 novel coronavirus diseases (COVID-19) in China”, Zhonghua Liuxingbingxue Zazhi, Vol. 41 No. 2, pp. 145.

Orel, F.D. and Kara, A. (2014), "Supermarket self-checkout service quality, customer satisfaction, and loyalty: Empirical evidence from an emerging market", Journal of Retailing and Consumer Services, Vol. 21 No. 2, pp. 118-129.

Parasuraman, A., Zeithaml, V.A. and Berry, L.L. (1985), "A conceptual model of service quality and its implications for future research", Journal of Marketing, Vol. 49 No. 4, pp. 41-50.

Qirici, E., Theodhori, O. and Elmazi, L. (2011), "E-marketing and ICT-Supported tourist destination management. Implications for tourism industry in global recession", International Journal of Management Cases, Vol. 13 No. 3, pp. 152-158.

Quach, T.N., Thaichon, P. and Jebarajakirthy, C. (2016), “Internet service providers' service quality and its effect on customer loyalty of different usage patterns", Journal of Retailing and Consumer Services, Vol. 29, pp. 104-113.

Rovetta, A. and Bhagavathula, A.S. (2020), "Covid-19-related web search behaviors and infodemic attitudes in italy: infodemiological study", JMIR Public Health and Surveillance, Vol. 6 No. 2, pp. e19374.

Roy, S.K., Kaur, G., Sharma, R. and Mahajan, N. (2012), "Exploring customer switching intentions through relationship marketing paradigm", International Journal of Bank Marketing,

Saccani, N., Visintin, F. and Rapaccini, M. (2014), "Investigating the linkages between service types and supplier relationships in servitized environments", International Journal of Production Economics, Vol. 149, pp. 226-238.

Safi, K.U. and Awan, T.M. (2018), "Impact of perceived service quality on customer loyalty: evidence from casual dining restaurants of Peshawar", City University Research Journal, Vol. 8 No. 1, pp. 30-46. 
$\mathrm{XJM}$

$17,1 / 2$

Sahu, P. (2020), "Closure of universities due to coronavirus disease 2019 (COVID-19): impact on education and mental health of students and academic staff", Cureus, Vol. 12 No. 4.

Santouridis, I. (2009), "E-Service quality and its impact on customer satisfaction and trust: an empirical study on Greek customers of internet shops", Paper presented at the Proceedings of the 6th International Conference on Enterprise Systems, Accounting and Logistics, Hessaloniki, Greece.

Seetharaman, P. (2020), "Business models shifts: Impact of covid-19", International Journal of Information Management, Vol. 54, p. 102173.

Shankar, A. and Jebarajakirthy, C. (2019), "The influence of e-banking service quality on customer loyalty", International Journal of Bank Marketing, Vol. 37 No. 5.

Singh, N., Srivastava, S. and Sinha, N. (2017), "Consumer preference and satisfaction of M-wallets: a study on North Indian consumers", International Journal of Bank Marketing, Vol. 35 No. 6.

SivaKumar, S., Naveen, R., Dhabliya, D., Shankar, B.M. and Rajesh, B.N. (2020), "Electronic currency note sterilizer machine", Materials Today: Proceedings,

Sivapalan, A. and Jebarajakirthy, C. (2017), "An application of retailing service quality practices influencing customer loyalty toward retailers”, Marketing Intelligence and Planning, Vol. 35 No. 7.

Suariedewi, I.G.A.A.M. and Suprapti, N.W.S. (2020), "Effect of mobile service quality to e-trust to develop e-satisfaction and e-loyalty mobile banking services. International research journal of management", IT and Social Sciences, Vol. 7 No. 1, pp. 185-196.

Thaichon, P., Lobo, A., Prentice, C. and Quach, T.N. (2014), "The development of service quality dimensions for internet service providers: retaining customers of different usage patterns", Journal of Retailing and Consumer Services, Vol. 21 No. 6, pp. 1047-1058.

U1 Haq, I., Paracha, A. and Shakeel, W. (2020), “A multiple parallel mediation between transformational leadership and project-based performance a process model”, Journal of Financial Engineering, Vol. 7 No. 1, p. 23.

Versteeg, G. and Bouwman, H. (2006), "Business architecture: a new paradigm to relate business strategy to ICT", Information Systems Frontiers, Vol. 8 No. 2, pp. 91-102.

Vilaseca-Requena, J., Torrent-Sellens, J. and Jiménez-Zarco, A.I. (2007), "ICT use in marketing as innovation success factor", European Journal of Innovation Management, Vol. 10 No. 2.

Wang, K.-Y. and Ma, Q. (2010), "An empirical investigation of product innovation and costomer loyalty in telecommunication industry", Paper presented at the 2nd International Conference on Information Science and Engineering.

Wójcik, D. and Ioannou, S. (2020), "COVID-19 and finance: market developments so far and potential impacts on the financial sector and centres", Tijdschrift Voor Economische en Sociale Geografie, Vol. 111 No. 3, pp. 387-400.

Wolfinbarger, M. and Gilly, M.C. (2003), "eTailQ: dimensionalizing, measuring and predicting etail quality”, Journal of Retailing, Vol. 79 No. 3, pp. 183-198.

Yi, L. and Thomas, H.R. (2007), "A review of research on the environmental impact of e-business and ICT”, Environment International, Vol. 33 No. 6, pp. 841-849.

Yu, P.L., Balaji, M. and Khong, K.W. (2015), "Building trust in internet banking: a trustworthiness perspective", Industrial Management and Data Systems, Vol. 115 No. 2.

Zhu, H., Wei, L. and Niu, P. (2020), "The novel coronavirus outbreak in Wuhan”, China. Global Health Research and Policy, Vol. 5 No. 1, pp. 1-3.

Ziaullah, M., Yi, F. and Akhter, S.N. (2014), "E-loyalty: the influence of product quality and delivery services on e-trust and e-satisfaction in China", International Journal of Advancements in Research and Technology, Vol. 3 No. 10, pp. 20-31. 


\begin{abstract}
About the authors
Inzamam U1 Haq is a young Research Scholar and Master of Science (Specializing in Finance) student at COMSATS University Islamabad, Pakistan. He loves to play cricket and is a die-hard cricket fan. His hobbies include exploring fresh research in his area of interest and new destinations. He has mixed research interests, particularly behavior finance, bank marketing, diversification, hedge, safehaven. Inzamam Ul Haq is the corresponding author and can be contacted at: inzamam.uh894@ gmail.com

Tahir Mumtaz Awan obtained PhD in Marketing from Sun Yat-sen Business School, Guangzhou, China. He is currently working as Assistant Professor of Marketing at COMSATS University Islamabad, Pakistan, and Research Fellow of China Brand Center, Academy of Entrepreneurship, Sun Yat-sen Business School, Guangzhou, China.
\end{abstract}

For instructions on how to order reprints of this article, please visit our website: www.emeraldgrouppublishing.com/licensing/reprints.htm Or contact us for further details: permissions@emeraldinsight.com 